\title{
An empirical analysis of India's trade in goods with BRICS
}

\author{
Javeria Maryam $^{1} \cdot$ Ashok Mittal $^{1}$ \\ Received: 13 November 2018 / Accepted: 24 May 2019 \\ (c) Springer-Verlag GmbH Germany, part of Springer Nature 2019
}

\begin{abstract}
The purpose of this paper is to examine the empirically the trade flows between India and BRICS. The bilateral revealed comparative advantage index (BRCA) is computed for the assessment of comparative advantages of exports by India to BRICS countries for period 2001-2015. In addition, the trade complementarity index (TCI) between India and remaining BRICS countries is examined. The study has employed the gravity model of trade to find the role of selected variables on promoting India's trade with BRICS countries. The findings of BRCA concluded that India holds a comparative advantage predominantly in agricultural and allied products followed by manufacturing and man-made products. BRCA analysis indicated minor structural changes between the years 2001 and 2015 for India's export basket with BRICS countries. The higher TCI values suggested the scope of trade potential between India and BRICS countries. The results of panel gravity model for exports, imports and trade showed that most of the variables have the expected sign and are statistically significant. Results suggested that among the other variables, GDPs of trading countries and population can explain export, import and total trade flows. One of the major findings of the gravity analysis confirmed that distance acts negative, as a major constraint in increasing the trade flows of India with BRICS.
\end{abstract}

Keywords BRICS $\cdot$ RCA $\cdot$ Gravity model $\cdot$ Panel data

JEL Classification F13 $\cdot$ F14 $\cdot$ F15

Javeria Maryam

javeriamaryam117@gmail.com

Ashok Mittal

askmittal@yahoo.com

1 D/o Economics, Aligarh Muslim University, Aligarh, India 


\section{Introduction}

In the current global scenario, the rise of economic integration expands the linkages of national income, employment generation, etc., among trading partners. International trade is described as the spine of an economy in the trade theories. Benefits of international trade are efficient use of resources, availability of commodities at lower prices and a wider choice of consumption. The contribution of developing economies group BRICS (Brazil, Russia, India, China and South Africa) in the regional and global economic growth has increased significantly. The term BRIC was coined in 2001 by Jim O' Neill, as the group with the potential to replace the giant economies of Europe in terms of market size. In 2010, South Africa has joined the group to make it BRICS. This group of five emerging economies can accelerate the process of economic development of member countries through collective economic cooperation. These economies collectively represent more than a quarter of the world's land area, forty-one percent world's demography. With a cumulative global trade of $20 \%$ and generating more than $30 \%$ of global economic growth, BRICS has the potential to accelerate the global trade. BRICS has made significant progress in the integration with the world economy. In the early 1990s, the contribution of BRICS in global trade was less than $4 \%$, at present BRICS represents more than $15 \%$ of global trade. With the expanding global trade flows, intra-BRICS trade relationship has improved over the time.

BRICS countries and India specifically as a prominent global leader need to strengthen their relationship by promoting intra-BRICS trade. The ascending cooperation among BRICS countries can be jointly advantageous for the group. BRICS countries have unique economic characteristics; for example, Brazil and Russia are the major producer and exporter of natural resources, India and China are the main exporters of manufactured and processed commodities, and South Africa provides a route for India-Brazil trade. Therefore, intra-BRICS cooperation is advocated to further aid economic growth of each member country. Table 1 gives the trend of intra-BRICS trade. Between 2001 and 2015, Brazil, Russia, India, China and South Africa's total trade with BRICS expanded positively. The data on exports highlight the increasing share of Brazilian exports with BRICS. Post-2010, South Africa has outperformed India, China and Russia in the exports flow to BRICS.

Table 1 Trend in intra-BRICS trade (2001-15). Source Trade Map, ITC

\begin{tabular}{|c|c|c|c|c|c|c|c|c|}
\hline \multirow[t]{2}{*}{ Country } & \multicolumn{4}{|c|}{ Export (percentage of total goods exports) } & \multicolumn{4}{|c|}{$\begin{array}{l}\text { Import (percentage of total goods } \\
\text { imports) }\end{array}$} \\
\hline & 2001 & 2005 & 2010 & 2015 & 2001 & 2005 & 2010 & 2015 \\
\hline Brazil & 6.4 & 10.3 & 20.1 & 22.5 & 4.9 & 10.5 & 18.4 & 22.5 \\
\hline Russia & 6.9 & 6.6 & 6.8 & 10.2 & 7.6 & 10.7 & 19.9 & 22.8 \\
\hline India & 5.5 & 10.2 & 11.9 & 6.8 & 7.9 & 11.2 & 15.7 & 19.6 \\
\hline China & 2.6 & 4.0 & 6.7 & 6.0 & 9.0 & 14.3 & 14.8 & 15.7 \\
\hline South Africa & 4.4 & 6.2 & 14.7 & 13.9 & 8.0 & 13.5 & 19.4 & 25.6 \\
\hline
\end{tabular}


The share of BRICS as a group in Chinese and Indian exports is not much higher as with member countries at individual levels. The exports data of Russia reflect the improvements post-2010 period (Table 1). The data on imports of BRICS countries reflect the consistently rising share of BRICS. Among the BRICS, China has been consistently the largest contributor to the group's total imports. China has contributed on average around 50\% imports to BRICS throughout the study period. The share of the remaining four member countries in BRICS imports also increased more rapidly compared to the exports flows. BRICS has emerged as the group representing the interests of developing the world. In the face of current global trade tensions, the rising alliance of BRICS as a grouping is becoming more coherent. While the BRICS trade with the world shows an upward trend, the intra-BRICS trade has remained comparatively low. The importance of India in BRICS is central, as its one of the rising economies of the world. In this context, the present paper is an attempt to examine the trade in goods between India and BRICS countries. This study has adopted BRCA index (bilateral revealed comparative advantage) to identify the top ten products of India with higher RCA value at the aggregate level with Brazil, Russia, China and South Africa. In addition, the trade complementarity index for India with BRICS countries is estimated, as the complementarity in the trade structure of partner countries facilitates more export and import between them. Further, to identify the factors promoting bilateral trade flows between India and BRICS, the study employed a gravity model of trade over the period 2001-2015. The remainder of the paper is organized into four sections: In Sect. 2, brief reviews of studies on revealed comparative advantage, trade complementarity index and gravity model of trade are provided, along with research gap. Section 3 discusses the data sources, reasons for the variables used and detailed methodology of tools employed to examine the India's bilateral trade with BRICS. The findings and interpretations are presented in Sect. 4, followed by concluding remarks in Sect. 5 .

\section{Review of literature}

In this section, a brief review of selected studies has been done and is divided into two subsections. Section 2.1 gives a review of studies that employed revealed comparative advantage (RCA) and trade complementarity indices followed by studies on gravity model of trade in Sect. 2.2.

\subsection{Revealed comparative advantage (RCA) and trade complementarity}

Balassa (1977) analyzed the pattern of comparative advantage of the industrial countries for the period 1953-1971. RCA indices have confirmed exports diversification and highlighted that with technical upgradation, the export diversifies. Yeats (1997) examined the possible alterations in the trade pattern due to the adoption of discriminatory trade barriers under the regional trading agreements MERCUSOR by using RCA indices. Richardson and Zhang (1999) employed RCA index to examine the pattern of variations across the time, sectors and regions for US trade. The study 
found over the time the presence of patterns differentiation across different countries and at different levels of data aggregation. Yue (2001) used RCA indices to demonstrate the fact that China has changed exports patterns to coincide with its comparative advantage basket of products. Batra and Khan (2005), Wignaraja (2011), Tian and Yu (2012) attempted to examine India and China's trade flows by using RCA index. Batra and Khan (2005) analysis revealed the differences in the pattern of comparative advantages at a different level of disaggregation. Wignaraja (2011) study highlighted the evidence for the divergent pattern of comparative advantage for the year 2009 between China and India. Tian and Yu (2012) study found India had a greater degree of consistency in its comparative advantage structure relative to China for the period 2000 and 2006.

Shinoj and Mathur (2008) study revealed that exports of various agricultural products of India had a different comparative advantage with respect to Asia for the period 1991-2004. Chandaran (2010) examined the trade complementarity and similarity of trade between India and ASEAN in the context of the regional trade agreement by using trade intensity and RCA indices. Findings showed the presence of higher export intensities compared to the import intensities for ASEAN. Pant (2011) observed the issue of trade and technology between India and BRICS countries for the period 1995-2007. The study found an increasing trend in ratio of net intraBRICS to net BRICS trade with the rest of the world at the four-digit level. In addition, study highlighted that the importance of BRICS trade with India has improved over the period. Castro (2012) while examining the trade intensities among BRIC during the period of 1995-2009 found a stronger bilateral trade flows not only at intra-BRIC levels, but also between EU and BRIC. Chatterjee et al. (2014) illustrated the trends and competitiveness among BRICS countries and its implication for India. The study highlighted that India is enjoying comparative advantage in many product categories, but it is also competing with other products. Kocourek (2015) used the revealed symmetric comparative advantage index to identify the comparative advantage of BRICS economies. The study found a continuous shift from primary manufacturing to sophisticated goods with low value added over the last two decades.

\subsection{Trade flows and gravity model}

Batra (2004) employed the gravity model to estimate the trade potential of India with its partner countries. Analysis revealed that India's trade potential magnitude was highest in the Asia-Pacific region followed by Western Europe and North America. Interestingly, the scope of expansion of trade based on the analysis was highest with the countries like China, the UK, Italy and France. Bhattacharya and Baneerjee (2006) by applying gravity model found India's trade responds less proportionally to size and more proportionally to distance and factors like colonial heritage and trading partner size played an important role in determining India's trade. De (2010) estimated the trade potentials for India in the post- and pre-financial crises by employing the augmented panel gravity model. The estimation of India's trade potential showed that the magnitude of India's trade is at its maximum level in Asia-Pacific region, followed by 
Africa and Latin America. The potential for trade expansion of trade in the post-crisis period was higher for countries like China. The study highlighted that tariff reductions and trade facilitation can promote further export momentum. Tripathi and Leitao (2013) examined the trade flow of India for the period 1998-2012 by employing gravity model technique. The analysis showed that variables like GDP per capita, political globalization, cultural proximity, distance and border have a positive and significant effect on trade flows. Chakravarty and Chakrabarty (2014) observed the Indo-ASEAN trade is influenced more by the distance than by country size. Dincier (2014) found that along with the GDP of turkey and BRICS, the R\&D expenditure of BRICS countries have positive correlation with Turkey' imports from BRICS. Kumar and Ahmed (2015) illustrated that variables GDP and population have positive effects and variables distance and tariff have negative in determining exports and imports flows of SAARC countries. The study also highlighted that the Free Trade Agreement (SAFTA) helped the trade creation among SAARC countries. Mishra et al. (2015) while examining the trade flows between India and BRICS countries by using a gravity model found the positive relationship between GNP and volume of trade. However, the transport cost found negative in influencing the trade. In this study, the variables like the exchange rate, import-GDP ratio and the inflation rate were found insignificant in influencing trade. Wani et al. (2016) applied gravity model to determine the variables stimulating India's imports for the period 1995-2015. The findings of the study highlighted that variables inflation, per capita income and openness of economy influenced imports of India. However, variables like border played important role for India and neighboring countries.

From the available literature survey, it is apparent that that most of the earlier studies focused mainly on bilateral trade analysis at country levels, for example India and China's bilateral trade. Very limited studies have addressed the research question related to intra-BRICS trade. Therefore, there is need to fill up the research gap by undertaking more systematic empirical and theoretical research to examine India's trade with BRICS.

\section{Data and methodology}

\subsection{Data}

In this study, we tried to analyze the trade in goods between India and BRICS for the period 2001-2015. The trade statistics required for the study are extracted from UN Comtrade, International Trade Centre (ITC), World Integrated Trade Solutions (WITS) database, World Development Indicator (WDI), Centre d'Etudes Prospectives et d'Information Internationales (CEPII) and BRICS Joint Statistical Reports.

\subsection{Methodology}

In this study, three different sets of methodologies are employed-bilateral revealed comparative advantage index (BRCA), trade complementarity index (TCI) and gravity model of trade. 


\subsubsection{Revealed comparative advantage (RCA)}

Balassa (1965) constructed an index to measure the country's revealed comparative advantage. Balassa index of RCA is defined as the ratio of a country's share in the world exports of a particular product to its share in the overall world trade. This index helps to assess the export potential of a country and provides information about the potential trade prospects with the partners. In the available literature, RCA index has been used extensively to examine the comparative advantage of exports and to capture the changing pattern of export structure over years. This index can also be used to calculate the comparative advantage for bilateral trade between countries, known as bilateral revealed comparative advantage (BRCA).

BRCA is calculated as:

$$
\operatorname{BRCA}_{i j}^{k}=\left(X_{i j}^{K} / X_{i j}\right) /\left(X_{w j}^{K} / X_{w j}\right)
$$

where $X_{i j}^{K}$ is the export of product $k$ from country $i$ to country $j$ and $X_{i j}$ is the total exports of country i to country j. $X_{w j}^{K}$ is the export of product $k$ from world to country $j$, and $X_{w j}$ is the total exports of the world to country $j$. The index has the same meaning as that of the RCA index in the bilateral market with respect to the global market share. In the present study, the BRCA index is calculated to measure the pattern of comparative advantage of India with Brazil, Russia, China and South Africa (BRCS) at the aggregate level (HS-two digits). However, Balassa index has been criticized for weak empirical distribution characteristics (Hinloop and Van Marrewik 2001; De Benedicts and Tamberi 2001). An attempt of refinement of Balassa index was undertaken by Laursen (1998) called new index as revealed symmetric comparative advantage (RSCA) to overcome the demerits of original index. While the innovations to make the RCA index more theoretically consistent with the Ricardian model continue, scope for practical applications of these alternatives is yet limited (Batra 2016). Balassa index has advantage over other improvements as it considers the intrinsic advantage of particular export product. In addition, the RCA index remains consistent with changes in an economy's relative factor endowment and productivity. The original index has simplicity in computation and interpretations that is why this index has wide applicability in most of the earlier studies.

\subsubsection{Trade complementarity index ( $\mathrm{TCl})$}

The trade complementarity is computed between India and each BRICS by using index introduced by Michaely (1996) to measure the degree to which two countries are "natural trading partners." The TCI between partner countries $k$ and $j$ is defined as:

$$
\mathrm{TC}_{k j}=100\left(1-\operatorname{sum}\left(\left|m_{i k}-x_{i j}\right| / 2\right)\right)
$$


where $x_{i j}$ is the share of good $i$ in the global exports of country $j$ and $m_{i k}$ is the share of good $i$ in country $k$ 's total imports. The index with zero value shows no exports or imports between partner countries. The index value is 100 when the trade profiles exactly match between the countries, meaning the exports and imports shares exactly match.

\subsubsection{Panel gravity model of trade}

The gravity model of trade is one of the most popular empirical tools to explain trade flows among trading partners. The empirical studies by Tinbergen (1962) and Poyhonen (1963) introduced core gravity model to international trade. The gravity model originates from the Newtonian physics notion, i.e., the two bodies attract each other proportionally to the product of their bodies mass divided by the square of the distance between their respective gravity centers

$$
F=G \frac{m_{1} \times m_{2}}{r^{2}}
$$

where $F$ is the force between masses; $m_{1}$ and $m_{2}$ are the masses of each bodies; $r^{2}$ is the distance between masses; and $G$ is gravitational constant. The gravity model of trade is analogous to original law, stating the trade between two countries is directly proportional to the product of each country's GDP and inversely proportional to the geographical distance between them.

The derived gravity equation for trade can be expressed as:

$$
\operatorname{Trade}_{i j}=\frac{\mathrm{GDP}_{i} \times \mathrm{GDP}_{j}}{\text { Distance }_{i j}}
$$

where trade $e_{i j}$ is the volume of trade between two trading countries $i$ and $j . \mathrm{GDP}_{i}$ and $\mathrm{GDP}_{j}$ are the national incomes of country $i$ and $j$ and distance ${ }_{i j}$ denotes the distance between two countries (as proxy of trade cost). The above equation is often transformed into a linear log form as follows:

$$
\log \left(\operatorname{Trade}_{i j}\right)=\alpha+\beta_{1} \log \left(\mathrm{GDP}_{i} \times \mathrm{GDP}_{j}\right)+\beta_{2} \log \left(\text { Distance }_{i j}\right)+\mu_{i j} .
$$

Equation (3) is core gravity model equation where trade is assumed as positive function of income and negative function of geographical distances. To estimate the trade effects for a particular time, the classical gravity model was based on the cross-sectional data. However, the panel data methodology has an advantage over cross-sectional data as it captures the relevant relationship among variables over time by using more information and combines both time series and cross-sectional data. Egger (2000) viewed that for disentangling time-invariant and country-specific effects, the panel data methodology is the most appropriate. The use of panel data methods allows minimization of bias generated by heterogeneity across countries. For our analysis, we have employed the panel data techniques for the gravity model of export, import and total trade flows. To choose between panel 
methods, i.e., fixed effects and random effects, Hausman test is generally applied. However, in the presence of few time-invariant variables, the fixed effect model is unable to evaluate them. Thus, we have used the panel OLS model based on the Breusch-Pagan-Lagrange multiplier value (prob $>$ chi2) 1.00, indicating that the panel OLS method is appropriate. Breusch-Pagan-Lagrange multiplier test helps to decide between the simple ordinary least squares regression and random effect regression.

One of the main motives behind every trade agreement is to reduce the trade barriers for maximum realization of trade gains. The barriers to trade are direct barriers, i.e., tariffs imposition, and the indirect barriers which are the factors that hamper the smooth flow of goods from exporters to importers, often known as transaction costs. In the literature, trade barriers are also categorized under trade costs. Based on Anderson and Wincoop (2004), the components of trade cost are transportation costs (freight and time costs), border-related barriers (language barrier, currency barrier, information costs, security barrier), policy barriers (tariffs and non-tariffs) and retail and wholesale distribution cost. Trade cost can be an option of substitution for distance among as it has wider impact on trade flows rather than distances alone as suggested in Anderson and Wincoop (2004), De (2007). However, due to the lack of compatible quantitative information, we have incorporated few components of trade cost, i.e., policy barriers (tariffs imposition) and border-related barriers (language), in the model as additional barriers along with the distances. The study employed the following augmented forms of gravity models:

Model for Exports:

$$
\begin{aligned}
\ln \left(X_{i j t}\right)= & B_{0}+\alpha_{i j}+\theta_{t}+B_{1} \ln \mathrm{GDP}_{i t}+B_{2} \ln \mathrm{GDP}_{j t}+B_{3} \ln \mathrm{POP}_{i t} \\
& +B_{4} \ln _{j \mathrm{POP}}+B_{5} \ln _{j A R_{j t}}+B_{6} \ln _{\mathrm{DIST}} \\
& +B_{7} \ln _{i j} \text { Contiguity }_{i j}+B_{8} \ln _{\text {Comlang }}+B_{9} \mathrm{RFE}+e_{i j t}
\end{aligned}
$$

Model for Imports:

$$
\begin{aligned}
\ln \left(M_{i j t}\right)= & B_{0}+\alpha_{i j}+\theta_{t}+B_{1} \ln \mathrm{GDP}_{i t}+B_{2} \ln \mathrm{GDP}_{j t}+B_{3} \ln \mathrm{POP}_{i t} \\
& +B_{4} \ln \mathrm{POP}_{j t}+B_{5} \ln \mathrm{TAR}_{j t}+B_{6} \ln \mathrm{DIST}_{i j} \\
& +B_{7} \ln _{\text {Contiguity }}+B_{8} \ln _{\text {Comlang }}+B_{9} \mathrm{RFE}+e_{i j t}
\end{aligned}
$$

Model for Total Trade:

$$
\begin{aligned}
\ln \left(T_{i j t}\right)= & B_{0}+\alpha_{i j}+\theta_{t}+B_{1} \ln \left(\mathrm{GDP}_{i t} * \mathrm{GDP}_{j t}\right)+B_{2} \ln \left(\mathrm{POP}_{i t} * \mathrm{POP}_{j t}\right) \\
& +B_{3} \ln \left(\mathrm{TAR}_{i t} * \mathrm{TAR}_{j t}\right)+B_{4} \ln \mathrm{DIST}_{i j} \\
& +B_{5} \ln _{\text {Contiguity }}+B_{6} \ln ^{\text {Comlang }_{i j}}+B_{7} \mathrm{RFE}+e_{i j t}
\end{aligned}
$$

where $\mathrm{X} i j$ denotes the exports between India (country $i$ ) and country $j$ in the time

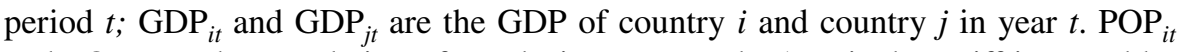
and $\mathrm{POP}_{j t}$ are the population of $i$ and $j$ in year $t$, and $\mathrm{TAR}_{j t}$ is the tariff imposed by the importing country on its imports. (In total trade model, TAR $\mathrm{R}_{i t}$ denotes tariffs 
imposed by India on the imports.) $D I S T_{i j}$ is the geographical distance between trading countries $i$ and $j$; Contiguity $i j$ is a binary/dummy variable which is unity if $i$ and $j$ share a common border and zero otherwise. Similarly, Comlang ${ }_{i j}$ is a binary/dummy variable, which is unity if $i$ and $j$ share a common language and zero otherwise. $R F E$ (relative factor endowments) is used as to measure the difference in terms of relative factor endowment between pair countries. The larger difference in RFE denotes the presence of higher volume of inter-industry trade and vice versa. In this model, RFE is taken as the absolute value of differences between logarithms of per capita GDPs between the pair countries as given below:

$$
\mathrm{RFE}_{i j}=\ln \mathrm{PGDP}_{i}-\ln \mathrm{PGDP}_{j} .
$$

Generally, relative factor endowment is measured by the difference between capital and labor ratio. Because the data are unavailable, we used the GDP per capita, as some of the recent studies Egger (2002), Baltagi et al. (2003) and Salim and Kabir (2010) used this method. In the model, $e_{i j t}$ denotes the error term; $\alpha_{i j}$ is individual effects, and $\theta_{t}$ is time-specific effects. For the panel gravity model, the variables are taken in nominal terms and are in millions.

\section{Estimation results}

\subsection{India's comparative advantage with BRICS}

The BRCA index is employed to investigate the following aspects: the pattern of comparative advantage for India in the BRICS member countries and to find the structural transformation of India's trade pattern with these countries between the period 2001 and 2015. For the comparison, the top ten products are selected based on higher RCA values in the examined year.

\subsubsection{Brazil}

Table 2 gives the comparison of BRCA index for India's export to Brazil for the year 2001 and 2015. The product with the maximum comparative advantage in 2001 is identified as silk. The other top products with high comparative advantage are coffee, tea, maté and spices; bird skin, feathers, artificial flowers, human hair; other vegetable textile fibers, paper yarn and woven fabrics of paper yarn and others. In the year 2015, cotton with the RCA value of 15.15 has the maximum revealed comparative advantage.

The products like vegetable textile fibers, paper yarn and woven fabrics of paper yarn and carpets and other textile floor coverings showed improvement in the ranks but with lower RCA values as compared to 2001. However, there is a drop in the ranks of products like bird skin, feathers, artificial flowers, human hair; lac, gums, resins and other vegetable saps and extracts; and articles of apparel and clothing accessories, not knitted or crocheted. Man-made filaments, strip and the man-made 


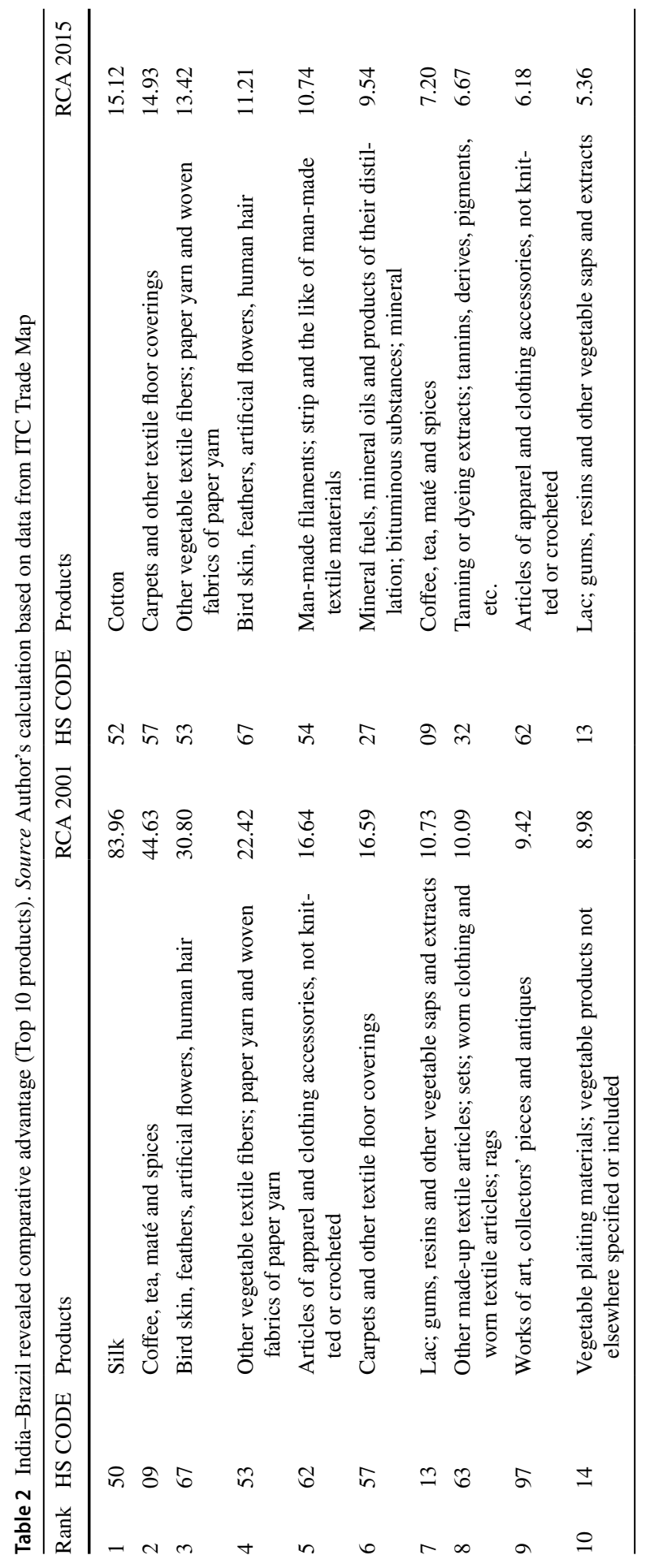


textile materials; mineral fuels, mineral oils, and products of their distillation, bituminous substances, mineral; coffee, tea, maté and spices; tanning or dyeing extracts; tannins, derives, pigments are products that appeared in the top ten products.

\subsubsection{Russia}

Table 3 reports the results of BRCA analysis for India's export to Russia. The product with the maximum comparative advantage in 2001 is identified under HS-61 (articles of apparel and clothing accessories, knitted or crocheted).

The other top products with high comparative advantage for India with Russia in 2001 are fertilizers; articles of apparel and clothing accessories, not knitted or crocheted; coffee, tea, maté and spices; silk, etc. With the improvement in the rankings, the product HS-41 (raw hides and skins (other than fur skins, and leather)) with the RCA value of 38.56 has the maximum comparative advantage in 2015. HS-13 (lac, gums, resins and other vegetables saps and extracts), HS-14 (vegetable plaiting materials; vegetable products not elsewhere specified or included), HS-10 (cereals), HS-57 (carpets and other textile floor coverings), HS-53 (other vegetable textile fibers) and HS-93 (arms and ammunition; arts and accessories thereof) are products that appeared in the top ten products.

\subsubsection{China}

Bilateral RCA analysis for India and China shows that the product with the maximum comparative advantage in 2001 is identified as HS-13 (lac; gums, resins, and other vegetable saps and extracts) as given in Table 4. Other products constituting top ten list with high comparative advantage for India with China in the year 2001 are HS-67 (prepared feathers and down and articles made of feathers; artificial flowers), HS-25 (salt, sulfur, earths and stone), HS-03 (fish and crustaceans, mollusks and other aquatic invertebrates), HS-26 (ores, slag and ash), HS-63 (other madeup textile articles), HS-09 (coffee, tea, mate and spices), HS-68 (articles of stone, plaster, cement, mica or similar materials), HS-65 (headgear and parts thereof) and HS-17 (sugar and sugar confectionery). With the improvement in the rankings, the HS-67 (prepared feathers and down and articles made of feathers or of down; artificial flowers; articles) with higher RCA value of 105.15 has been placed at the top place in 2015.

There is a drop in the rankings of the product like HS-13 (lac; gums, resins and other vegetable saps and extracts), HS-25 (salt, sulfur, earths and stone) and HS-09 (coffee, tea, mate and spices). HS-50 (silk), HS-52(cotton), HS-14 (vegetable plaiting materials), HS-57 (carpets and other textile floor coverings), HS-79 (zinc and articles thereof) and HS-53 (other vegetable textile fibers; paper yarn and woven fabrics of paper yarn) are new products that appeared in the top 10 products with high comparative advantages in 2015. The RCA index values are found higher in 2015 comparatively 2001 . 


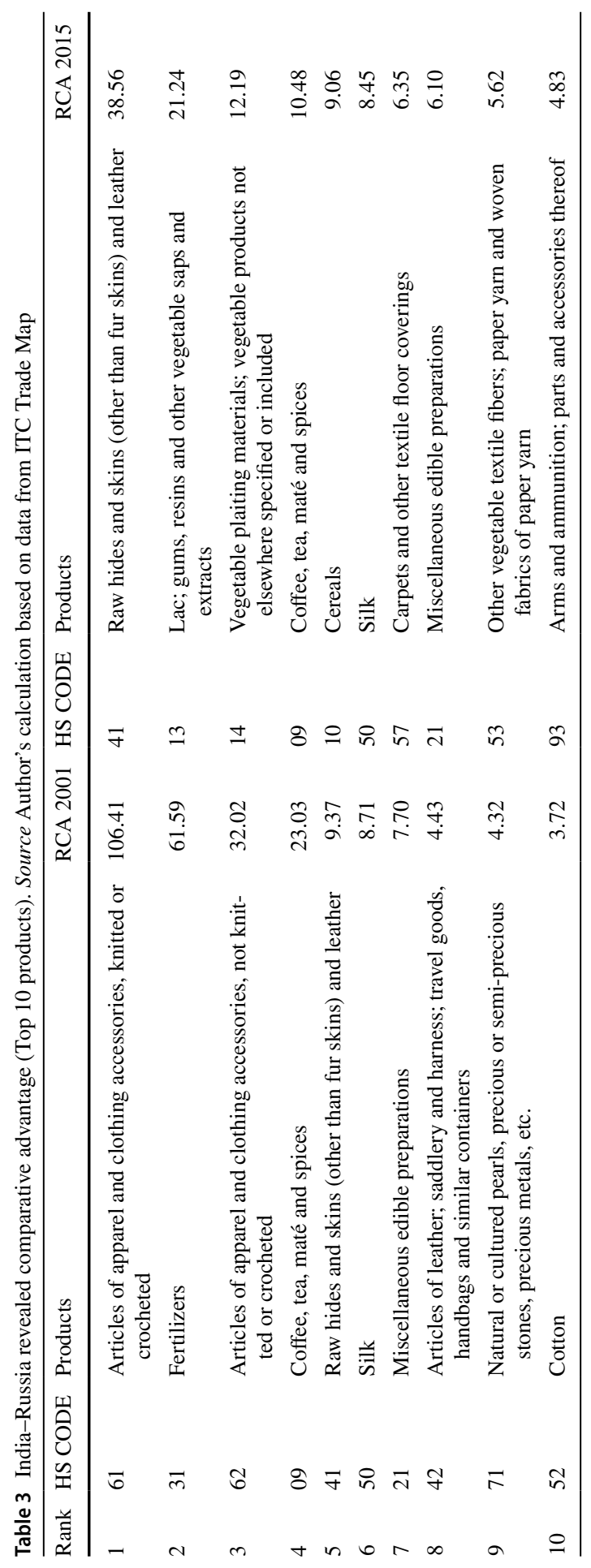




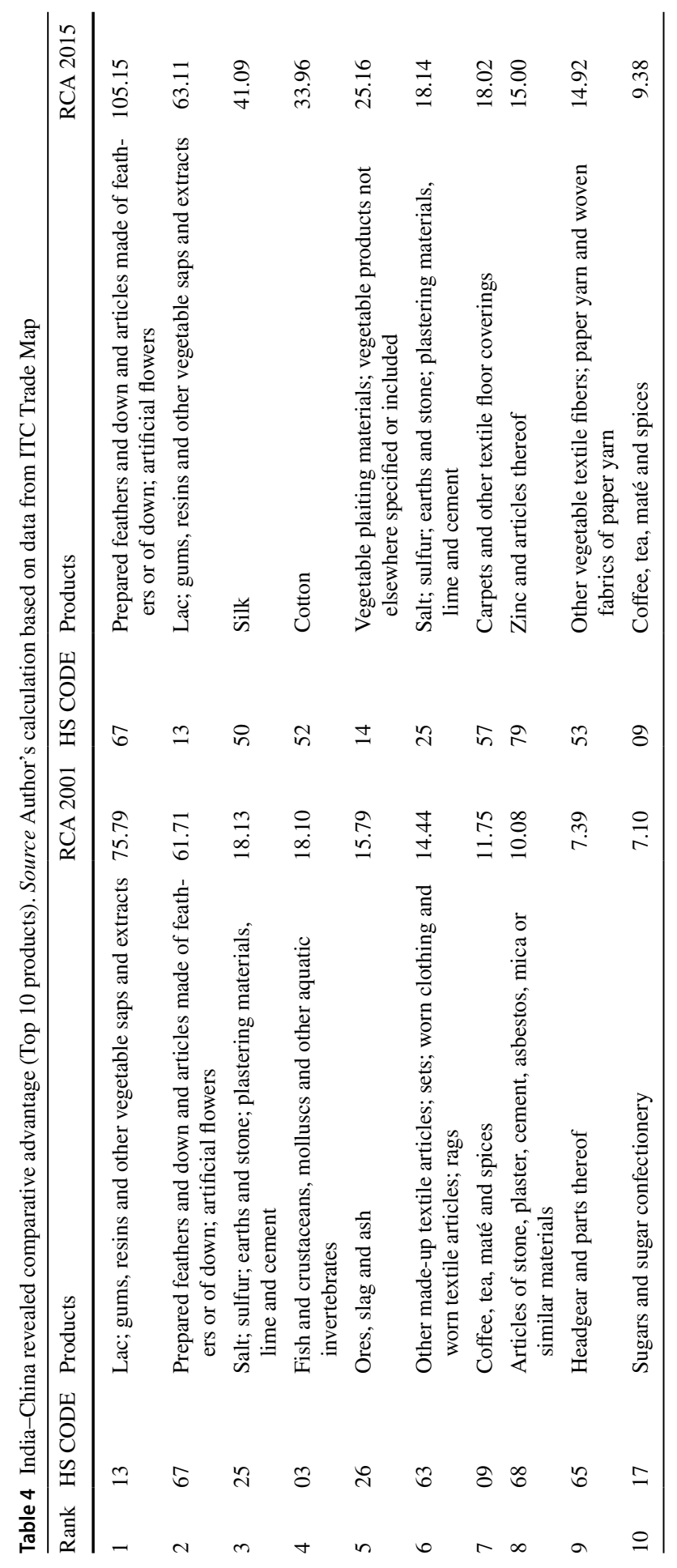




\subsubsection{South Africa}

Table 5 reports the comparison of bilateral RCA index values for India's export to South Africa for the year 2001 and 2015. The product with the maximum comparative advantage in 2001 is identified as HS-50 (silk).Other top products with high comparative advantage are HS-62(articles of apparel and clothing accessories, not knitted or crocheted), HS-63 (other made-up textile articles; sets; worn clothing and worn textile articles; rags), HS-13 (lac; gums, resins and other vegetable saps and extracts), HS-52 (cotton), HS-53 (other vegetable textile fibers; paper yarn and woven fabrics of paper yarn), HS-03 (fish and crustaceans, mollusks and other aquatic invertebrates), and others as given in Table 5. The HS-89 (ships, boats and floating structures) with the RCA value of 56.61 has the maximum comparative advantage in 2015. There is a drop in the ranks of products like HS-63 (other madeup textile articles; sets; worn clothing and worn textile articles; rags) and HS-13 (lac; gums, resins and other vegetable saps and extracts).

The HS-57 (carpets and other textile floor coverings), HS-41 (raw hides and skins (other than fur skins) and leather), HS-30 (pharmaceutical products), HS-03 (fish and crustaceans, mollusks and other aquatic invertebrates), HS-61 (articles of apparel and clothing accessories, knitted or crocheted) and HS-55 (man-made staple fibers) are products that appeared in the top ten products. The comparative analysis of BRCA for 2001 and 2015 highlights the shift of India's exports from primary products to manufacturing products.

\subsection{Estimation results for trade complementarity}

For the promotion and expansion of intra-regional trade, it is generally argued in trade theory that the trade profiles of partner countries should match. The changes in the value of TCI over time can help to determine whether the trade profiles of countries under consideration are growing more or less compatible ( $\mathrm{Ng}$ and Yeats 2003). Table 6 reports the trade complementarity indices for India's trade with Brazil, Russia, China and South Africa. The degree of complementarity between India and Brazil has improved over time 2001-2015 and was higher compared to other countries in the region. The trade complementarity between India and Russia was low among the other BRICS members over the period 2001-2015, highlighting the lack of strong trade complementarities in the bilateral trade between them. The TCI value between India and China has improved over the time. With the minor fluctuations, the TCI value reached highest 53.94 in the year 2015. Similarly, South Africa has turned out with strong trade complementarities structure with India.

The overall findings showed that the trade complementarities have increased between India and trading partners in the BRICS region. The higher TCI values suggested that India's intra-regional trade with BRICS member countries has the potential to increase remarkably. 


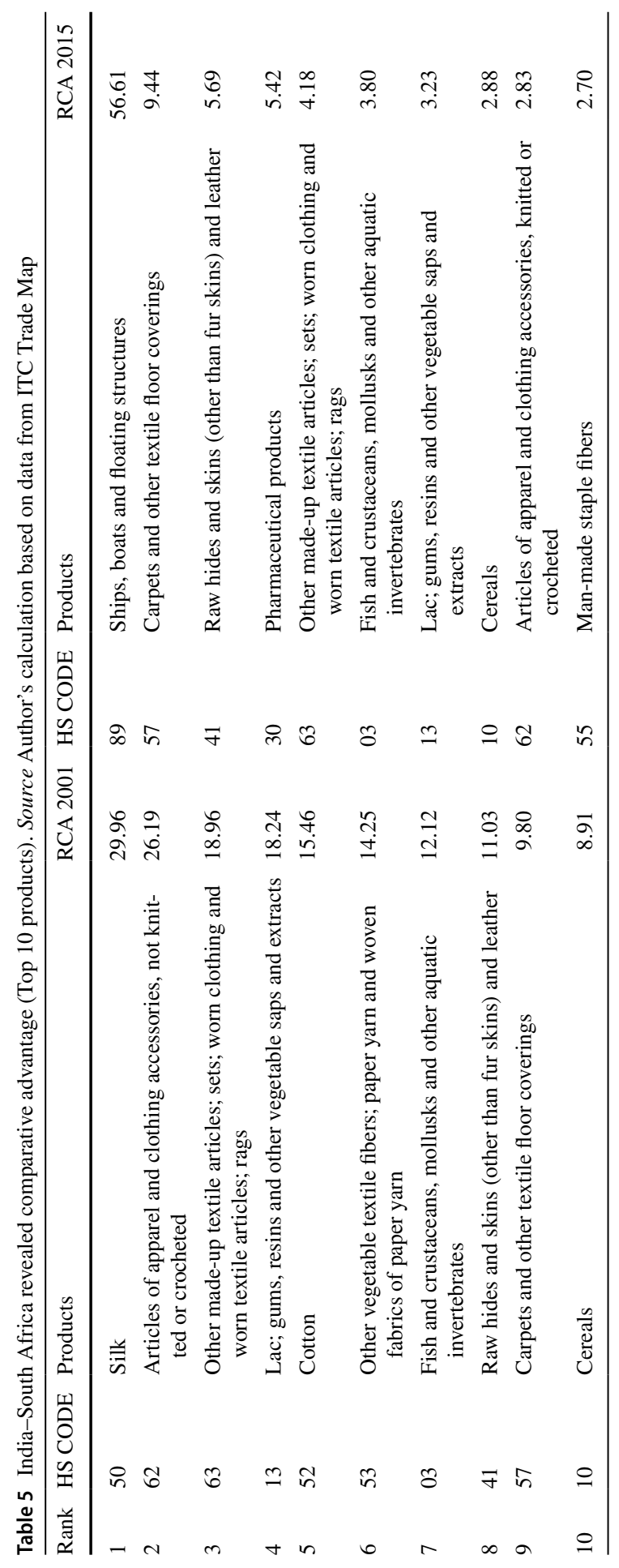




\begin{tabular}{llllll}
\cline { 2 - 5 } $\begin{array}{l}\text { Table 6 India-BRICS: trade } \\
\text { complementarity index. Source }\end{array}$ & Year & Brazil & Russia & China & South Africa \\
\cline { 2 - 6 } Author's calculation based on & 2001 & 42.66 & 45.69 & 41.92 & 42.10 \\
data from ITC Trade Map & 2002 & 43.28 & 43.38 & 42.09 & 42.36 \\
& 2003 & 45.89 & 43.56 & 44.40 & 44.86 \\
& 2004 & 47.42 & 43.91 & 47.99 & 46.70 \\
& 2005 & 49.69 & 42.88 & 48.86 & 48.77 \\
& 2006 & 56.26 & 42.36 & 49.57 & 52.49 \\
& 2007 & 56.87 & 42.22 & 48.85 & 53.36 \\
& 2008 & 59.51 & 43.58 & 52.42 & 56.63 \\
& 2009 & 56.97 & 47.36 & 50.29 & 54.34 \\
& 2010 & 59.76 & 44.63 & 52.47 & 58.17 \\
& 2011 & 60.14 & 45.84 & 52.98 & 59.14 \\
& 2012 & 60.48 & 44.83 & 52.46 & 58.83 \\
& 2013 & 61.59 & 45.89 & 51.25 & 60.16 \\
& 2014 & 62.46 & 48.94 & 52.66 & 59.24 \\
& 2015 & 60.22 & 53.76 & 53.94 & 55.95 \\
\hline
\end{tabular}

\subsection{Estimation results gravity model}

In this study, the gravity model of trade is employed to capture the pattern and behavior of bilateral trade flows. However, if the analysis motive is to undertake the welfare effects resulted from bilateral trade, then the application of methodologies like computable general equilibrium (CGE) modeling is to be preferred. For the economic growth, trade is considered as an integral part; therefore, promotion of trade will reap benefits for economic growth. To identify the fundamentals of trade flows, an empirical examination of the impact of various variables on the trade flows between BRICS and India will help in the enhancement of trade volume. In this context, this study investigates the determinants of trade flows between India and the remaining four BRICS countries, namely Brazil, Russia, China and South Africa, by employing the augmented gravity model. The first subsection of the explains the results of gravity model from exports point of view, followed by the imports point of view in the second subsection and the total trade in the third subsection.

\subsubsection{Exports model}

The results of the augmented gravity model for exports are reported in Table 7. The study found most of the explanatory variables in the model are statistically significant with the expected coefficients, indicating the gravity model as effective in explaining the bilateral trade flows between India and other BRICS countries. The GDP of exporting country (India) is highly significant with the estimated coefficient 1.43 , implying that with the $1 \%$ increase in the GDP of India, its exports with a trading country increase by $1.43 \%$. Similarly, the GDP of the importing country is 
Table 7 Results of gravity model exports (2001-2015).

Sources Author's calculation

\begin{tabular}{|c|c|}
\hline Variable & $\begin{array}{l}\text { Estimated } \\
\text { values of coef- } \\
\text { ficients }\end{array}$ \\
\hline$L n \mathrm{GDP}_{i t}$ & $\begin{array}{l}1.439 \\
(0.034)^{*}\end{array}$ \\
\hline$L n \mathrm{GDP}_{j t}$ & $\begin{array}{l}0.460 \\
(0.141)\end{array}$ \\
\hline$L n \mathrm{POP}_{i t}$ & $\begin{array}{l}-10.084 \\
(0.011)^{*}\end{array}$ \\
\hline$L n \mathrm{POP}_{j t}$ & $\begin{array}{l}12.557 \\
(0.000)^{*}\end{array}$ \\
\hline$L n \mathrm{TAR}_{j t}$ & $\begin{array}{l}-0.439 \\
(0.006)^{*}\end{array}$ \\
\hline Ln Distance $_{i j}$ & $\begin{array}{l}-2.858 \\
(0.000)^{*}\end{array}$ \\
\hline Comlang & $\begin{array}{l}16.66 \\
(0.000)^{*}\end{array}$ \\
\hline Contiguity & $\begin{array}{l}-27.324 \\
(0.000)^{*}\end{array}$ \\
\hline RFE & $\begin{array}{l}0.099 \\
(0.564)\end{array}$ \\
\hline Constant & $\begin{array}{l}-19.85 \\
(0.800)\end{array}$ \\
\hline$R$-sq Overall & 0.944 \\
\hline Prob $>$ chi $^{2}$ & 0.000 \\
\hline
\end{tabular}

$p$ values in parentheses $(* p<0.05)$

positively related to the exports from country $i$. The analysis provides evidence that a larger size of population creates wider opportunities for trade between countries. In our analysis, the variable POPi has found to be statistically significant but has the negative coefficient.

The negative coefficient of the exporting country implies that with the increase in the population, the exports decrease by $-10.08 \%$. However, the coefficient of POPj is found positive with value 12.55 , meaning that the increase in the population of importing country aids the exports from country $i$ to $j$. The coefficient of the population of the exporters may carry negative or positive sign depending on whether the country exports less when it is big or whether a country exports more as compared to a small country (Martínez-Zarzoso and Nowak-Lehmann 2003). The analysis found the sign for the coefficient of TARjt as negative, suggesting that tariff imposed by the importing country decreases magnitude of partners' exports. In the model, the coefficient of distance came out negative as expected, implying that the more distant countries are, the less trade will take place. The dummy variable Comlang in the model is found significant at $1 \%$ with the positive coefficient, highlighting the importance of common language to promote exports between the trading partners. The coefficient of other dummy variable 
Contiguity came out negative. This suggests though India only shares its border with China among BRICS countries, the role of contiguity in promoting trade is negative. As per the neoclassical trade theory of Heckscher-Ohlin, trade between two countries takes place based on the comparative advantage resulting from the differences in factor endowments. With the larger difference in the factor endowments between countries, it is likely that the inter-industry trade is likely to be larger. However, the intra-industry is expected to be larger among the nations of the same size and factor proportion. In our analysis, the RFE has the positive coefficient reflecting the presence of intra-industry trade between India and BRICS.

\subsubsection{Results of imports}

Table 8 presents the results of panel gravity for imports between India and BRICS for the period 2001-2015. In this model, the imports between India and other BRICS countries are taken as dependent variable. In our analysis, the majority of the explanatory variables are found statistically insignificant with the expected

Table 8 Results of gravity model imports (2001-2015). Sources Author's calculation

\begin{tabular}{|c|c|}
\hline Variable & $\begin{array}{l}\text { Estimated values of } \\
\text { coefficients }\end{array}$ \\
\hline Ln $\mathrm{GDP}_{i t}$ & $\begin{array}{l}0.683 \\
(0.363)\end{array}$ \\
\hline$L n \mathrm{GDP}_{j t}$ & $\begin{array}{l}0.687 \\
(0.036)^{*}\end{array}$ \\
\hline$L n \mathrm{POP}_{i t}$ & $\begin{array}{l}-0.307 \\
(0.940)\end{array}$ \\
\hline$L n \mathrm{POP}_{j t}$ & $\begin{array}{l}1.453 \\
(0.451)\end{array}$ \\
\hline$L n \mathrm{TAR}_{j t}$ & $\begin{array}{l}-0.246 \\
(0.097)\end{array}$ \\
\hline Ln Distance $_{i j}$ & $\begin{array}{l}-0.763 \\
(0.143)\end{array}$ \\
\hline Comlang & $\begin{array}{l}3.64 \\
(0.174)\end{array}$ \\
\hline Contiguity & $\begin{array}{l}-2.124 \\
(0.644)\end{array}$ \\
\hline RFE & $\begin{array}{l}0.109 \\
(0.542)\end{array}$ \\
\hline Constant & $\begin{array}{l}-24.57 \\
(0.756)\end{array}$ \\
\hline$R$-sq overall & 0.95 \\
\hline Prob $>$ chi 2 & 0.000 \\
\hline
\end{tabular}

$p$ values in parentheses $(* p<0.05)$ 
coefficients. In this model, we expect the distance between countries and tariff imposed by India to be negative. GDP of the host country (India) is found statistically insignificant, but its expected positive coefficient suggests that as the income level of the importing country increases, so does the country's demand for imports. In the model, only the GDP of exporting country (here BRICS countries) has found to be significant. The positive coefficient of GDP $j$ is 0.68 which suggests that with $1 \%$ increment in the GDP of the exporting country, its exports with the importing country will increase by $0.68 \%$.

The coefficient of country $\mathrm{POP}_{i}$ has found to be negative and insignificant as opposed to what has been expected. However, the positive coefficient of $\mathrm{POP}_{j}$ suggests that with the rise in population in country $j$, the bilateral trade increases. The results show that the coefficient of TARjt is expectedly negative but not statistically significant, implying that an increase in tariff will reduce bilateral trade. In the model, the estimated coefficient of distance has anticipated the negative sign, which suggests that trade between pair countries falls by $0.76 \%$ for every $1 \%$ increase in the distance between them. The dummy variable Comlang sign is positive but statistically insignificant. The dummy variable Contiguity has a negative coefficient; the sign of variable is opposite to as expected. In our analysis, the RFE has a positive coefficient reflecting the presence of intra-industry trade between India and BRICS.

Table 9 Results of gravity model total trade (2001-2015). Sources Author's calculation

\begin{tabular}{ll}
\hline Variable & $\begin{array}{l}\text { Estimated values of } \\
\text { coefficients }\end{array}$ \\
\hline Ln $\mathrm{GDP}_{i j t}$ & 0.480 \\
& $(0.038)^{*}$ \\
Ln POP $_{i j t}$ & 3.723 \\
& $(0.000)^{*}$ \\
Ln TAR $_{j t}$ & -0.345 \\
& $(0.000)^{*}$ \\
Ln Distance & \\
& -1.046 \\
Comlang & $(0.000)^{*}$ \\
& 5.991 \\
Contiguity & $(0.000)^{*}$ \\
& -7.177 \\
RFE & $(0.000)^{*}$ \\
& 0.279 \\
Constant & $(0.025)^{*}$ \\
$R$-sq overall & -143.39 \\
Prob $>$ chi2 & $(0.000)$ \\
\hline
\end{tabular}

$p$ values in parentheses $(* p<0.05)$ 


\subsubsection{Results of total trade}

Table 9 presents the results for the OLS estimates of the augmented gravity model for trade. In this model, the total trade (exports plus imports) has been taken as the dependent variable for the analysis of bilateral trade flows between India and BRICS. The regression results reported that estimated coefficients and level of significance of the explanatory variables and dummies. The estimated coefficients on $\mathrm{GDP}_{i}$ and $\mathrm{GDP}_{j}$ have a positive sign, at $1 \%$ statistically significance level. The positive coefficients of both the pair countries indicate the higher GDP aids the trade magnitude. The estimated coefficient on POPij has the anticipated positive sign, indicating that the increase in the size of population creates wider opportunities for trade between countries. The higher positive coefficient of 3.72 of the population suggests that with the $1 \%$ increase in the population of the pair countries, the trade is increased by $3.72 \%$ between them.

The results show the expected sign for the coefficient on $\mathrm{TAR}_{j t}$ as negative and statistically significant. The negative coefficient of tariff means that with the increase in tariff imposition by the country, the bilateral trade declines. The coefficient of variable distance has found to be negative as expected implying that the more trade will take place when countries are the less distant. Sharing a common language increases the trade by economically and significant levels. The dummy variable Comlang in the model is found significant at $1 \%$ with the positive coefficient of 5.99. The other dummy variable Contiguity is statistically significant but with a negative coefficient. The analysis reveals that the contiguity has surprisingly low role in promoting trade between India and other BRICS countries.

The intra-industry is expected to be larger among the nations of the same size and factor proportion. In our analysis, the RFE has found to be statistically significant with the positive coefficient reflecting the presence of intra-industry trade between India and BRICS.

\section{Conclusion}

In the present era, the multitude of international economic agreements, whether under the multilateral framework or under bilateral or regional arrangements, has an influence on the global trade and investment policymaking. In this scenario, for BRICS it has become a major arena to assert their growing role in the world economy and put influence on key issues underpinning trade and investment. The bilateral revealed comparative advantage analysis (BRCA) of India with each BRICS member countries at aggregate level highlights that India enjoys comparative advantage predominantly in agricultural and allied products followed by manufacturing and man-made products. BRCA analysis also indicates minor structural changes in India's export basket with BRICS countries between the 2001 and 2015 period. Based on the BRCA analysis, this study suggests that there is need to promote the share of product in exports in which India holds comparative advantage. The measured degree of complementarities revealed the improvement in the degree of complementarity between India and BRICS countries over the period 2001-2015. 
Among the BRICS, India has highest trade complementarity with Brazil among the BRICS. With Russia, the trade complementarity has shown upward trend but at lower pace comparatively with other members. For India and China, the analysis revealed improvement in the degree of complementarity during the study period. Over the period, South Africa has turned out with strong trade complementarities structure with India. The higher values of trade complementarity index values suggest the scope of trade potential between India and BRICS countries.

Further, the present study has employed the gravity model of trade to examine the underlying factors to promote bilateral trade flows of India with other BRICS members. The findings of panel gravity model for exports, imports and trade show that most of the variables have the expected sign and are statistically significant. The results suggest that among the other variables, income of trading countries and population can explain trade flows. Growth in economic size of India and partner countries has a positive impact on the bilateral trade flows between them. The positive relationship between GDPs and trade flows is also evident in studies by Batra (2004) and Bhattacharya and Baneerjee (2006). In the model, the coefficient of distance came out negative, implying that the more distant countries are, the less trade will take place. The finding of negative proximity of distance on bilateral trade flows is supported by the studies of Batra (2004), Bhattacharya and Baneerjee (2006) and Ghatak et al. (2009). Similarly, the imposition of higher tariff rates by importers shrinks the trade flow between trading partners. Among the BRICS countries, India shares its border only with China and the study suggests that contiguity is not an important factor in boosting trade flow between India and BRICS. However, on the other hand, sharing a common language can help in stimulating the trade and similar relationship is found in earlier literature (Batra 2004) also. The identification of these trade determinants can help India to enhance the volume of bilateral trade flows with BRICS members. One of the major findings of the gravity analysis confirmed that distance acts as a major constraint in increasing the trade flows of India with BRICS. So in this regard, the government must try to adopt those steps that can trim down the transport cost, improve trade facilitation and reduce other non-tariff barriers. This study suggests for adoption of trade policies with motive to simplify exports and imports procedures of India to further strengthen trade ties with BRICS.

\section{Compliance with ethical standards}

Conflict of interest The authors declare that they have no conflict of interest.

\section{References}

Anderson JE, Eric Van Wincoop E (2004) Trade costs. J Econ Lit 42(3):691-751

Balassa B (1965) Trade liberalisation and 'revealed' comparative advantage. Manch Sch 33(2):99-123

Balassa B (1977) Revealed comparative advantage revisited: an analysis of relative export shares of the industrial countries. Manch Sch Econ Soc Stud 45(4):327-344 
Baltagi BH, Egger P, Pfaffermayr M (2003) A generalized design for bilateral trade flow models. Econ Lett 80:391-397

Batra A (2004) India's global trade potential: the gravity model approach. Working paper (151), ICRIER

Batra A (2016) Revealed comparative advantage and gravity model analysis of trade patterns and regional economic integration, empirical evidence in the Indian context. TIES golden jubliee monograph (series-1). Academic Foundation, New Delhi

Batra A, Khan Z (2005) Revealed comparative advantage: an analysis for India and China. Working paper (168), ICRIER

Bhattacharyya R, Baneerjee T (2006) Does the gravity model explain India's direction of trade? A panel data approach. Working paper (2006-09-01). IIM Ahmedabad

BRICS Joint Statistical Publications (2017)

Castro TD (2012) Trade cooperation indicators: development of BRIC bilateral trade flows. Int Rev Bus Res Pap 8(1):211-223

Chakravarty SL, Chakrabarty R (2014) A gravity model approach to indo-ASEAN trade fluctuations and swings. Proc Soc Behav Sci 133:383-391

Chandaran S (2010) Trade complementarity and similarity between India and ASEAN in the context of RTA. MPRA Paper No. (29279)

Chatterjee B, Jeena PC, Singh S (2014). Intra-BRICS trade and its implication for India. Discussion paper CUTS

De P (2007) Impact of trade costs on trade: empirical evidence from Asian countries (No. 27). ARTNeT Working paper series

De P (2010) Global economic and financial crisis: India's trade potential and prospects, and implications for Asian regional integration. J Econ Integr 25(1):32-68

De Benedicts L, Tamberi M (2001) Overall specialization empirics: techniques and applications. Open Econ Rev 15:323-346

Dincier G (2014) Turkey's rising imports from BRICS: a gravity model approach. MPRA Paper No. (61979)

Egger P (2000) A note on the proper econometric specification of the gravity equation. Econ Lett 66(1):25-31

Egger P (2002) An econometric view on the estimation of gravity models and the calculation of trade potentials. World Econ 25:297-312

Ghatak S, Silaghi M, Daly V (2009) Trade and migration flows between some CEE countries and UK. J Int Trade Econ Dev 18(1):61-78

Hinloop J, Van Marrewijk C (2001) On the empirical distribution of the Balassa index. Rev World Econ Weltwirtschaftliches Arch 137:1-35

Kocourek A (2015) Structural changes in comparative advantage of the BRICS. Proc Soc Behav Sci 172:10-17

Kumar S, Ahmed S (2015) Gravity model by panel data approach: an empirical application with implications for South Asian countries. Foreign Trade Rev 50(4):233-249

Laursen K (1998) Revealed comparative advantage and the alternatives as measure of international specialization. Danish Research Unit for Industrial Dynamics DRUID Working Paper (No. 98-30). Copenhagen, Denmark

Martínez-Zarzoso I, Nowak-Lehmann FD (2003) Augmented gravity model: an empirical application to Mercosur-European Union trade flows. J Appl Econ 6(2):291-316

Michaely M (1996) Trade preferential agreements in Latin America: An Ex ante assessment. Policy research working paper series, The World Bank, No. (1583)

Mishra AK, Ghadia JN, Kubendran N, Sahoo M (2015) Trade flows between India and other BRICS countries: an empirical analysis using gravity model. Glob Bus Rev 16(1):107-122

Neill JO (2001) Building Better Global Economic BRICs. Goldman Sachs, global economics paper No 66

$\mathrm{Ng} \mathrm{F}$, Yeats A (2003) Major trade trends in east Asia: what are their implications for regional cooperation and growth. Policy research working paper series, The World bank 3084

Pant M (2011). India and the BRICS countries: issues of trade and technology. Working paper. Centre for WTO Studies, IIFT, New Delhi

Poyhonn P (1963) A tentative model for the volume of trade between countries. Weltwirtshaftliches Arch 90:93-99 
Richardson DJ, Zhang C (1999) Revealing comparative advantage: chaotic or coherent patterns across time and sector and U.S trading partner? Working paper (7212). National Bureau of Economic Research

Salim R, Kabir S (2010) The immediate impact of euro on intra-regional trade: an event study approach. J Econ Dev 35(3):43-55

Shinoj P, Mathur VC (2008) Comparative advantage of India in agricultural exports vis-à-vis Asia: a post-reforms analysis. Agric Econ Res Rev 21(1):60-66

Tian W, Yu M (2012) China and India: trends in trade over the last decade. J China Glob Econ $1(1): 27-38$

Tinbergen J (1962) Shaping the world economy: suggestions for an international economic policy. Twentieth Century Fund, New York

Tripathi S, Leitao LN (2013). India's trade and gravity model: a static and dynamic panel data. MPRA paper no. (45502)

Wani NH, Dhami JK, Rehman A (2016) The determinants of India's imports: a gravity model approach. MPRA paper no. (74700)

Wignaraja G (2011). Economic reforms, regionalism and exports: comparing China and India. Policy studies 60. East-West Center, Honolulu, Hawaii

Yeats AJ (1997). Does Mercosur's trade performance raise concerns about the effects of regional trade arrangements. International Economics Department, The World Bank

Yue C (2001) Comparative advantage, exchange rate and exports in China. In: Paper for the international conference on Chinese economy. CERDI, France

Publisher's Note Springer Nature remains neutral with regard to jurisdictional claims in published maps and institutional affiliations. 